\title{
FORMATION OF PLUM SEEDLINGS UNDER DRIP IRRIGATION IN CENTRAL NON-BLACK SOIL REGION OF RUSSIA
}

\author{
Nikolai N. Dubenok, Aleksandr V. Gemonov, \\ Aleksandr V. Lebedev, Elena V. Glushenkova \\ Russian State Agrarian University - Moscow Timiryazev Agricultural Academy \\ Moscow, 127550, Russian Federation \\ ndubenok@mail.ru
}

\begin{abstract}
The article presents the results of studying formation of plum seedlings under drip irrigation in conditions of the Central Non-Black Soil Region of Russia. Field research was carried out on the territory of the training and experimental farming, fruit-growing laboratory "Michurinsky Garden" of the Russian State Agrarian University - Moscow Timiryazev Agricultural Academy. The factors studied were soil irrigation regimes $(60-80,70-90,80-100 \%$ of the lowest moisture capacity) and plum varieties ("Utro" and "Mashenka"). The results of the experiment showed that plum seedlings grown under conditions of insufficient and uneven moistening were characterized by the lowest biometric indices. The most severe lack of soil moisture was observed during intensive growth (May - early June). Insufficient and uneven moistening with intervals of reduced moistening leads to several growth waves in plants. In the seedlings grown under drip irrigation the second and third waves of growth were not observed. In irrigation variants, the root system of seedlings was mainly located in the upper arable layer of the soil which was best supplied with nutrients, had the lowest density and favorable air regime. Location of root system along the drip line and at the depth of $30 \mathrm{~cm}$ facilitated transferring seedlings to nurseries and ensured less damage to them during transplantation.
\end{abstract}

Key words: drip irrigation, irrigation regime, seedlings, plum

\section{INTRODUCTION}

Despite potential opportunities, gardening in Russia is not able to meet the population's requirements of fruit and berry products within the recommended annual physiological rate of $90-100 \mathrm{~kg}$ per person [1-3]. Russia is among the top ten countries in terms of consumption of fruit and berry products being also one of their major importers in the world. With the annual consumption of plum being about 180 thousand tons, the share of imports is $25-35 \%$.

Today, most of the imported fruit adapted to the climatic conditions of Russia, can be replaced with Russian substitutes. Despite the fact that in recent years much attention has been paid to horticulture, it is quite difficult for producers to achieve sustainable indicators in the market and to increase the economic efficiency of production. According to the Federal State Statistics Service, the area under the perennial plantations of fruit and berry crops annually declines by 5-10 thousand hectares, which is due to the extermination of extensive gardens made in the XX century and no longer meeting modern requirements. Gardens of intensive type occupy about $10 \%$ of the area [4]. 
On August 7, 2014, according to the Decree of the President of the Russian Federation No. 560 of August 6, 2014, a number of goods were banned from being imported into Russia from the United States of America, all countries of the European Union, Canada, Australia and Norway. In 2010 - 2014, before the ban was imposed, the share of plum imports from the countries of the European Union was approximately $25 \%$ of the total volume of imported products. No fruit imports create opportunities for Russian agricultural producers to fill the niche in the market.

At present, the problem of food security is actively discussed by public authorities of all levels. According to V.A. Dadalko [5], food security should be considered as an opportunity of the goverment and the ability of the domestic agribusiness to produce and supply the domestic market and state food reserves with food resources in the required assortment, sufficient quantities and of proper quality. In accordance with the federal target programs "Development of agricultural land reclamation in Russia for 2014 - 2020" and "Development of horticulture and nurseries in the Russian Federation for 2012 - 2014 with the continuation of activities until 2020" areas of horticultural facilities are to be expanded, which will contribute to solving the problem of the country's food security.

One of the ways to intensify agricultural production in horticulture and plant growing is to increase the efficiency of nature management through resource-saving technologies $[6,7]$. One of such technologies is drip irrigation, which allows improving quality and yield of farm crops [8-10]. At present, there are no scientific based resource-saving technologies for growing plum seedlings in nurseries of the Non-Black Soil Region of Russia. Therefore, the aim of the study was to determine influence of variations of soil moisture availability on the growth and development of plum seedlings and to develop effective regime for nursery moistening in the Non-Black Soil Region.

\section{MATERIALS AND METHODS}

Drip irrigation refers to resource-saving methods of watering farm crops. It is widespread in arid zones but is also relevant in areas with excessive moisture where precipitation is unevenly throughout the year, especially during plant growing season. Drip irrigation is possibility to irrigate in accordance with biological characteristics of water consumption in irrigated crops and maintain soil moisture in optimal range.

Field research was carried out on the territory of the training and experimental the fruit growing laboratory "Michurinsky Garden" of the Russian State Agrarian University - Moscow Timiryazev Agricultural Academy. Despite the geographical position, the natural and climatic conditions are close to the average values for the NonBlack Soil Region. Two-factorial experiment was carried out there in spring 2016 to study the effect of different moistening on formation of two plum seedlings varieties. The scheme of the experiment (Figure 1) included four variants (factor A) for the regime of soil moistening:

- maintaining humidity $60-80 \%$ of the lowest moisture capacity;

- maintaining humidity $70-90 \%$ of the lowest moisture capacity;

- maintaining of humidity $80-100 \%$ of the lowest moisture capacity;

- control (without irrigation). 
The proposed irrigation regimes, where the soil moisture content is maintained in a narrow range, allow not only to increase the efficiency of irrigation water use and to reduce the water consumption, but also maintain a more optimal water and air regimes. Moreover, the design features of drip irrigation allow to maintaining soil moisture in small ranges through increase in frequency of irrigation with small amounts of water in accordance with crop biological needs.

The second factor was plum varieties — "Mashenka" and "Utro" (factor B). Planting of seedlings was carried out according to the scheme of $0.9 \times 0.33 \mathrm{~m}$, i.e. the distance between the rows of one variant was $90 \mathrm{~cm}$, and the distance between the plants in the row was $33 \mathrm{~cm}$, while the distance between adjacent rows of different variants was $1 \mathrm{~m}$. This scheme provides planting density of 33.5 thousand plants per ha.

All variants of the experiment had 3-fold replication with a systematic arrangement of the plots. The plot area was $40 \mathrm{~m}^{2}, 30$ seedlings of each variety were planted in each replication. The total area of the pilot site was $930 \mathrm{~m}^{2}$. The total number of plum trees planted was 1080 . For carrying out biometric measurements and phenological observations, 24 countable plants and 6 protective plants, 1 plant at the beginning and end of the row, were isolated on each plot.

Productivity assessment of non-fruiting plants was impossible, the main biological indicators characterizing growth of seedlings (diameter of the stem, height of plants, leaf area of one seedling) were measured to determine the optimal irrigation regime.

The experimental site is located on sod-podzolic, cultivated, soil-gley, deep-till, medium loamy soil on moraine loam lined at the depth of $150-170 \mathrm{~cm}$ by submerged sands.

During the research, there were used data of Mikhelson Meteorological Observatory of the Russian State Agrarian University - Moscow Timiryazev Agricultural Academy, which is located in close proximity to the experimental site.

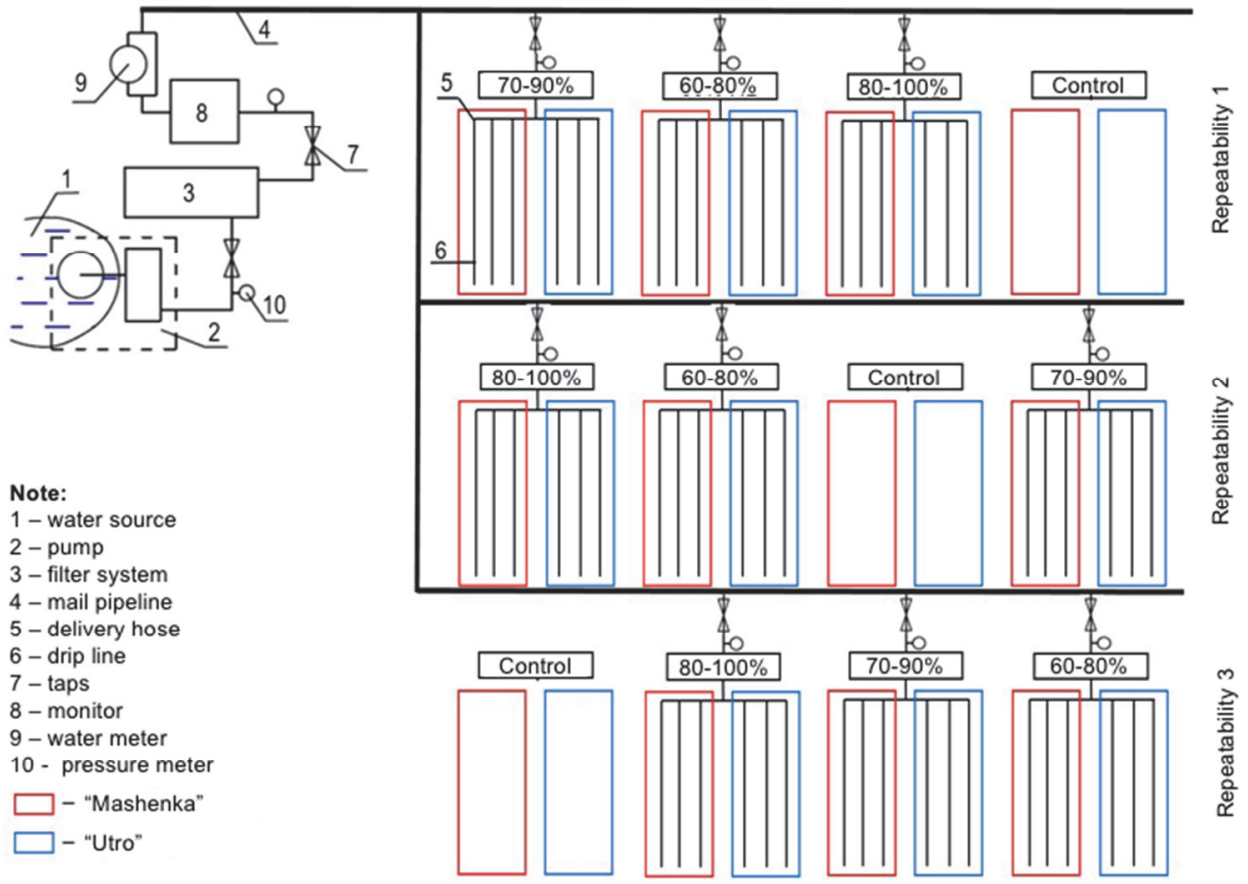

Fig. 1. The scheme for setting up a two-factor experiment 
For irrigation there was used a perennial drip line, equipped with built-in droppers with an autocompensation system, i.e., with a change in working pressure due to the silicone membrane, a constant flow rate of $3.8 \mathrm{l} / \mathrm{h}$ was maintained. The moisture content of the soil was monitored with the help of tensiometers calibrated depending on the data of the thermostatic-weight method.

\section{RESULTS AND DISCUSSION}

The choice of irrigation regime (frequency of irrigation, irrigation rate) was affected by actual soil moisture depended on climatic parameters such as air temperature and precipitation. The vegetation season of 2016 was characterized by uneven precipitation: precipitation deficit of $32.9 \%$ of the long-term value was observed in June, excess of precipitation over the long-term value in August was 94.9\%. The summer months of 2016 were $8.3-17.5 \%$ warmer than the average values.

Maximum irrigation rates are typical of the most moisturized options, but the irrigation rate in 2017 was higher than in 2016 . This was due to the climatic features of the years: the year 2016 turned out to have a more uneven precipitation than 2017 . The analysis of the data (Table 1) reveals that increased soil moisture leads to greater water consumption, and, consequently, flow of water to maintain such a level of moistening increases. Irrigation rates in such variants increased due to the increase in frequency of irrigation. Frequent waterings make it possible to avoid dramatic fluctuations in soil moisture, and plants were not subjected to periodic stresses caused by moisture deficit. In 2017, irrigation rates were 10-20\% lower compared to the previous year.

Characteristics of irrigation regimes in 2016-2017

Table 1

\begin{tabular}{|l|c|c|c|c|c|c|c|c|}
\hline \multirow{2}{*}{ Index } & \multicolumn{4}{|c|}{ Irrigation option, percent of the lowest moisture capacity } \\
\cline { 2 - 9 } & \multicolumn{2}{|c|}{$60-80 \%$} & \multicolumn{2}{c|}{$70-90 \%$} & \multicolumn{2}{c|}{$80-100 \%$} & \multicolumn{3}{c|}{ Control } \\
\cline { 2 - 9 } & $\begin{array}{c}2016 \\
\text { year }\end{array}$ & $\begin{array}{c}2017 \\
\text { year }\end{array}$ & $\begin{array}{c}2016 \\
\text { year }\end{array}$ & $\begin{array}{c}2017 \\
\text { year }\end{array}$ & $\begin{array}{c}2016 \\
\text { year }\end{array}$ & $\begin{array}{c}2017 \\
\text { year }\end{array}$ & $\begin{array}{c}2016 \\
\text { year }\end{array}$ & $\begin{array}{c}2017 \\
\text { year }\end{array}$ \\
\hline Irrigation rate, $\mathrm{m}^{3} / \mathrm{ha}$ & 1473 & 985 & 1574 & 890 & 1397 & 1242 & $\mathrm{x}$ & $\mathrm{x}$ \\
\hline Average irrigation rate, $\mathrm{m}^{3} / \mathrm{ha}$ & 47.5 & 39.4 & 46.3 & 37.5 & 38.8 & 44.4 & $\mathrm{x}$ & $\mathrm{x}$ \\
\hline Number of waterings & 31 & 25 & 34 & 25 & 36 & 29 & $\mathrm{x}$ & $\mathrm{x}$ \\
\hline
\end{tabular}

Biennial seedlings are not fertile, so there is no possibility of assessing their productivity through the yield indicator. V.I. Maidebur, V.M. Vasyuta, I.M. Merezhko, V.V. Burkovsky [9] point out that it is necessary to select high-quality seedlings with vigorous growth for planting in a garden, focusing on such parameters as stem diameter, branching, plant height, annual shoots growth, leaf surface area, quality of the root system. Many authors have shown that the diameter of the seedlings is an indicator that allows the most accurate assessment of the quality of the planting material $[1,10]$.

According to the results of the experiment, the maximum seedling stem diameter was obtained in the most moistened variants of the experiment: while maintaining humidity in the range of $80-100 \%$ of the lowest moisture capacity and $70-90 \%$ of the lowest moisture capacity. Both plum varieties "Mashenka" and "Utro" were responsive to soil moisture increasing, since plum is a moisture-requiring fruit crop. Comparing with the control variant without irrigation stem diameter in variants with irrigation was $15-25 \%$ larger. Thus, seedlings grown under drip irrigation had the best quality of planting material. 
Two-year-old seddlings of variety "Utro" were $15-20 \%$ higher than that of "Mashenka". One-year-old seedlings were more sensitive to irrigation. Here the differences with the control variant reached $35 \%$, and in the two-year-old seedlings - 30\%. In 2016, the greatest increase in height had the most moistened variants of the experiment. In 2017, due to the cold summer, there were no clear differentiation of the annual growth in height among variants with irrigation. Plants grown under irrigation had increase in growth of $5-15 \%$ more than plants in the control grown without irrigation.

Leaf surface area which determines the photosynthetic potential of plants is an indicator of quality and productivity of seedlings. The largest leaf surface area is formed in the most moistened irrigation variants. Leaf surface area of two-year "Utro" seedlings was larger than in "Mashenka" plants. In the variant with maintenance of soil moisture at the level of $80-100 \%$ of the lowest moisture capacity, the area of the leaf surface of one "Utro" plant was $635 \mathrm{~cm}^{2}$, and in "Mashenka" plant $-576 \mathrm{~cm}^{2}$.

An important indicator that determines quality of planting material of fruit crops is its age. Currently, among gardeners there is no single scientifically based opinion on the recommended age of planting material. Two-year-old seedlings seem to be preferred [14]. Thus, results of the experiment for the annual and biennial seedlings have shown than the most optimal conditions were while maintaining the soil moisture in the range of $80-100 \%$ of the lowest moisture capacity.

Table 2

Morphometric indices of plum seedlings depending on the variants and research years

\begin{tabular}{|c|c|c|c|c|c|c|c|c|c|c|c|c|}
\hline \multirow{2}{*}{$\begin{array}{c}\text { Experi- } \\
\text { ment } \\
\text { options }\end{array}$} & \multicolumn{3}{|c|}{ Stem diameter, $\mathrm{mm}$} & \multicolumn{3}{|c|}{ Height of plants, $\mathrm{cm}$} & \multicolumn{3}{|c|}{$\begin{array}{l}\text { Annual growth } \\
\text { of shoots, } \mathrm{cm}\end{array}$} & \multicolumn{3}{|c|}{$\begin{array}{c}\text { The leaf area } \\
\text { of one seedling, } \mathrm{cm}^{2}\end{array}$} \\
\hline & $\begin{array}{c}\text { Variety } \\
\text { "Ma- } \\
\text { shenka" }\end{array}$ & $\begin{array}{l}\text { Vari- } \\
\text { ety } \\
\text { "Utro" }\end{array}$ & $\begin{array}{l}\text { Mean } \\
\text { values }\end{array}$ & $\begin{array}{c}\text { Variety } \\
\text { "Ma- } \\
\text { shenka" }\end{array}$ & $\begin{array}{l}\text { Variety } \\
\text { "Utro" }\end{array}$ & $\begin{array}{c}\text { Mean } \\
\text { values }\end{array}$ & $\begin{array}{c}\text { Variety } \\
\text { "Ma- } \\
\text { shenka" }\end{array}$ & $\begin{array}{l}\text { Variety } \\
\text { "Utro" }\end{array}$ & $\begin{array}{l}\text { Mean } \\
\text { values }\end{array}$ & $\begin{array}{c}\text { Variety } \\
\text { "Ma- } \\
\text { shenka" }\end{array}$ & $\begin{array}{l}\text { Variety } \\
\text { "Utro" }\end{array}$ & $\begin{array}{l}\text { Mean } \\
\text { values }\end{array}$ \\
\hline \multicolumn{13}{|c|}{2016 year } \\
\hline Control & 8.3 & 8.7 & 8.5 & 26.7 & 28.1 & 27.4 & 15.6 & 17.4 & 16.5 & 135 & 131 & 133 \\
\hline $60-80 \%$ & 9.2 & 9.4 & 9.3 & 27.4 & 29.3 & 28.35 & 17.2 & 18.3 & 17.75 & 153 & 166 & 159.5 \\
\hline $70-90 \%$ & 10.7 & 11.5 & 11.1 & 33.5 & 34.3 & 33.9 & 24.3 & 25.6 & 24.95 & 174 & 181 & 177.5 \\
\hline $\begin{array}{l}80- \\
100 \%\end{array}$ & 12.3 & 12.1 & 12.2 & 35.4 & 36.7 & 36.05 & 25.8 & 27.4 & 26.6 & 188 & 192 & 190 \\
\hline Average & 10.1 & 10.4 & $\mathrm{x}$ & 30.8 & 32.1 & $\mathrm{x}$ & 20.7 & 22.2 & $x$ & 162.5 & 167.5 & $x$ \\
\hline \multicolumn{3}{|c|}{$\begin{array}{l}\mathrm{LSD}_{0.05} \text { for private } \\
\text { differences }\end{array}$} & 1.0 & \multicolumn{3}{|c|}{3.07} & \multicolumn{3}{|c|}{2.2} & \multicolumn{3}{|c|}{18.9} \\
\hline \multicolumn{3}{|c|}{$\mathrm{LSD}_{0.05}$ (irrigation regime) } & 0.9 & \multicolumn{3}{|c|}{2.8} & \multicolumn{3}{|c|}{2.0} & \multicolumn{3}{|c|}{16.4} \\
\hline \multicolumn{3}{|c|}{ LSD $_{0.05}$ (variety) } & 0.4 & & 1.3 & & & 0.8 & & & 9.3 & \\
\hline \multicolumn{13}{|c|}{2017 year } \\
\hline Control & 10.5 & 11.2 & 10.9 & 63.9 & 74.3 & 69.1 & 37.2 & 46.2 & 41.7 & 356 & 378 & 367 \\
\hline $60-80 \%$ & 12.3 & 13.1 & 12.7 & 71.4 & 78.1 & 74.75 & 44.0 & 48.8 & 46.4 & 395 & 452 & 423.5 \\
\hline $70-90 \%$ & 12.8 & 13.4 & 13.1 & 75.3 & 82.1 & \begin{tabular}{|l|}
78.7 \\
\end{tabular} & 41.8 & 47.8 & 44.8 & 483 & 534 & 508.5 \\
\hline $\begin{array}{l}80- \\
100 \%\end{array}$ & 13.0 & 13.5 & 13.3 & 76.4 & 85.3 & 80.85 & 41.0 & 48.6 & 44.8 & 576 & 635 & 605.5 \\
\hline Average & 12.2 & 12.8 & $\mathrm{x}$ & 71.8 & 80.0 & $x$ & 41.0 & 47.9 & $x$ & 452.5 & 499,8 & $x$ \\
\hline \multicolumn{3}{|c|}{$\begin{array}{l}\mathrm{LSD}_{0.05} \text { for private } \\
\text { differences }\end{array}$} & 1.3 & \multicolumn{3}{|c|}{7.8} & \multicolumn{3}{|c|}{4.8} & \multicolumn{3}{|c|}{51.1} \\
\hline \multirow{2}{*}{\multicolumn{3}{|c|}{$\mathrm{LSD}_{0.05}$ (irrigation regime) }} & 1.1 & \multicolumn{3}{|c|}{7.2} & \multicolumn{3}{|c|}{4.2} & \multicolumn{3}{|c|}{46.8} \\
\hline & & & 0.6 & \multicolumn{3}{|c|}{3.2} & \multicolumn{3}{|c|}{2.3} & \multicolumn{3}{|c|}{20.4} \\
\hline
\end{tabular}


The degree of soil moistening and the distribution of moisture along the profile had a significant effect on growth rates of seedling root system. The effect of irrigation regimes on development of root system is shown in Table 3. The largest mean values of root volume, number of roots and average root length were obtained in the variant with maintaining soil moisture in the range of $80-100 \%$ of the lowest moisture capacity. In the first year of this variant of experiment, the root volume was $154 \mathrm{ml}(285.2 \%$ more than in control), the number of roots - 21 (300.0\% more than in control) and an average root length of $24.9 \mathrm{~cm}$ (162.7\% more than in control). In the second year of experience, the volume of roots was $354 \mathrm{ml}(292.6 \%$ more than in control), the number of roots 47 (247.4\% more than control) and the average length of the root $-26.9 \mathrm{~cm}(146.2 \%$ more than in control).

It is important to note that the root system in the variants of the irrigation experiment was mainly located in the upper arable layer of soil which was best provided with nutrients, had the lowest density and favorable air regime. In addition, this horizon warms upquickly, resulting in optimal conditions for the development of seedlings.

Table 3

Basic indicators of root system growth of plum seedlings

\begin{tabular}{|c|c|c|c|c|c|c|}
\hline \multirow[t]{2}{*}{ Irrigation regime } & \multicolumn{2}{|c|}{ Volume of roots } & \multicolumn{2}{|c|}{ Number of roots } & \multicolumn{2}{|c|}{ Average root length } \\
\hline & $\mathrm{cm}^{3}$ & $\%$ to control & number & $\%$ to control & $\mathrm{cm}$ & $\%$ to control \\
\hline \multicolumn{7}{|c|}{2016 year } \\
\hline Control & 54 & 100.0 & 7 & 100.0 & 15.3 & 100.0 \\
\hline $60-80 \%$ & 104 & 192.6 & 12 & 171.4 & 17.4 & 113.7 \\
\hline $70-90 \%$ & 143 & 264.8 & 16 & 228.6 & 21.8 & 142.5 \\
\hline $80-100 \%$ & 154 & 285.2 & 21 & 300.0 & 24.9 & 162.7 \\
\hline $\mathrm{LSD}_{005}$ & 36.5 & - & 3 & - & 3.1 & - \\
\hline \multicolumn{7}{|c|}{2017 year } \\
\hline Control & 121 & 100.0 & 19 & 100.0 & 18.4 & 100.0 \\
\hline $60-80 \%$ & 243 & 200.8 & 28 & 147.4 & 23.2 & 126.1 \\
\hline $70-90 \%$ & 295 & 243.8 & 36 & 189.5 & 22.9 & 124.5 \\
\hline $80-100 \%$ & 354 & 292.6 & 47 & 247.4 & 26.9 & 146.2 \\
\hline $\mathrm{LSD}_{0.05}$ & 95.5 & - & 7 & - & 5.3 & - \\
\hline
\end{tabular}

Root system of seedlings formed conical shapein the control variant without irrigation. The major direction of root growth was downward toward the more humid layers, breaking through the compacted sub-plow horizon. In variants with irrigation, root system spread in the upper $30 \mathrm{~cm}$ layer and extended along the drop line. This arrangement facilitatedtransplanting of seedlings to nurseries and led to less damage during transplantation.

\section{CONCLUSIONS}

1. The results of the experiment showed that plum seedlings grown under conditions of insufficient and uneven moistening were characterized by the lowest biometric indices. Biometric indices of plants allowed us to conclude that the most optimal variant was drip irrigation regime with maintaining soil moisture in the range of $80-100 \%$ of the lowest moisture capacity. 
2. The most severe scarcity of soil moisture wasobserved during the period of intensive growth (May - early June). Insufficient and uneven moistening with intervals of reduced moistening caused several growth waves in seedlings grown under drip irrigation, the second and third waves of growth were not observed.

3. The most intensive development of the root system of plum seedlings was in the variant with a constant maintenance of soil moisture in the range of $80-100 \%$ of the lowest moisture capacity. Drip irrigation contributed to the constant provision of seedlings with sufficient amount of available moisture with dissolved nutrients in the root zone.

4. In irrigated plants, the root system of seedlings was mainly located in the upper arable layer of the soil, provided with nutrients, had the lowest density and favorable air regime. The location of the root system along the drip line and at the depth of $30 \mathrm{~cm}$ facilitatedtransplanting seedlings to nurseries and led to their less damage during transplantation.

@N.N. Dubenok, A.V. Gemonov, A.V. Lebedev, E.V. Glushenkova, 2019.

\section{REFERENCES}

[1] Kravtsov SA. Role of the government in development of horticulture in Russia. Horticulture and Viticulture. 2010; (5):14-19. (In Russ).

[2] Trunov YV, Medvedev SM. The state and prospects for the development of gardening in the Central Federal District. Horticulture and Viticulture. 2009; (5):16-17. (In Russ).

[3] Chekmarev PA. The state and prospects of development of vegetable growing and gardening in the Russian Federation. Horticulture and Viticulture. 2010; (3):5-14. (In Russ).

[4] Trunov YV, Solov'ev AV. The state and prospects of development of gardening in Russia. Technological features of modern gardening. Bulletin of Michurinsk State Agrarian University. 2012; (3):42 - 49. (In Russ).

[5] Dadalko VA. Food security as a component of national and state economic security. Vestnik UGATU. 2013; 17(7):17-25. (In Russ).

[6] Kulikov IM, Minakov IA. The development of horticulture in Russia: trends, problems, prospects. Agricultural Science Euro-North-East. 2017; (1):9-15. (In Russ).

[7] Kulikov IM, Minakov IA. The status and effectiveness of the intensification of horticulture. AIC: economics, management. 2017; (4):4-15. (In Russ).

[8] Dubenok NN, Borodychev VV, Lytov MN, Belik OA. Special features of soil water regime with trickle irrigation of crops. Achievements of Science and Technology of AIC. 2009; (4):22-25. (In Russ).

[9] Dubenok NN, Borodychev VV, Shentseva EV, Strizhakova EA, Shumakova KB. Growing eggplant under drip irrigation using the tunnel shelter for early production. Achievements of Science and Technology of AIC. 2012; (9):38 - 42. (In Russ).

[10] Dubenok NN, Borodychev VV, Bogdanenko MP, Vybornov VV, Shumakova KB. Tekhnologiya vozdelyvaniya rannego repchatogo luka pri kapel'nom oroshenii [Cultivation technology of early onion under drip irrigation]. Moscow: Prospekt Publ.; 2016. (In Russ).

[11] Buntsevich LL, Shcheglov SN, Kostyuk MA, Besedina EN. Studying of growing efficiency of early maturing and high yielding apple saplings on the rootstocks of "super-standard" category. Fruit growing and viticulture of South Russia. 2014; 26(2):12-20. (In Russ).

[12] Maidebura VI, Vasyuta VM, Merezhko IM, Burkovskii VV. Growing fruit and berry seedlings. Kiev: Urozhai Publ.; 1984. (In Russ). 
[13] Merezhko IM. Quality of planting material and productivity of fruit trees. Kiev: Urozhai Publ.; 1991. (In Russ).

[14] Pereira AR, Green S, Nova NAV. Penman-Monteith reference evapotranspiration adapted to estimate irrigated tree transpiration. Agricultural water management. 2006; 83(1-2):153161. Available from: doi: 10.1016/j.agwat.2005.11.004.

\title{
INFORMATION ABOUT AUTHORS
}

Dubenok Nikolai Nikolaevich - Academician of the Russian Academy of Sciences, Professor, Doctor of Agricultural Sciences, Head of the Department of Agricultural Land Reclamation, Forestry and Land Management, Russian State Agrarian University - Moscow Timiryazev Agricultural Academy; e-mail: ndubenok@mail.ru, eLibrary SPIN-code 1856-9793

Gemonov Aleksandr Vladimirovich - PhD Student, Department of Agricultural Land Reclamation, Forestry and Land Management, Russian State Agrarian University - Moscow Timiryazev Agricultural Academy; e-mail: agemonov@yandex.ru, eLibrary SPIN-код 3293-5840

Lebedev Aleksandr Vyacheslavovich - PhD Student, Department of Agricultural Land Reclamation, Forestry and Land Management, Russian State Agrarian University - Moscow Timiryazev Agricultural Academy; e-mail: mail@lebedev.fun, eLibrary SPIN-code 5789-5540

Glushenkova Elena Vladimirovna - Candidate of Philological Sciences, Associate Professor, Department of Foreign Languages Russian State Agrarian University - Moscow Timiryazev Agricultural Academy; e-mail: agemonov@yandex.ru.

\section{For citation:}

Dubenok N.N., Gemonov A.V., Lebedev A.V., Glushenkova E.V. Formation of plum seedlings under drip irrigation in Central Non-Black Soil Region of Russia. RUDN Journal of Agronomy and Animal Industries, 2019, 14 (1), 40 - 48. doi: 10.22363/2312-797X-2019-14-1-40-48.

\section{ФОРМИРОВАНИЕ САЖЕНЦЕВ СЛИВЫ ПРИ КАПЕЛЬНОМ ОРОШЕНИИ В УСЛОВИЯХ ЦЕНТРАЛЬНОГО НЕЧЕРНОЗЕМЬЯ}

\author{
Н.Н. Дубенок, А.В. Гемонов, А.В. Лебедев, \\ Е.В. Глушенкова \\ Российский государственный аграрный университет - \\ Московская сельскохозяйственная академия имени К.А. Тимирязева \\ Москва, Российская Федераџия, 127550
}

\begin{abstract}
Аннотация. В статье представлены результаты изучения формирования саженцев сливы при капельном орошении в условиях Центрального Нечерноземья. Полевые исследования проводились на территории учебно-опытного хозяйства, лаборатории плодоводства «Мичуринский сад» Российского государственного аграрного университета - MCXА имени К.А. Тимирязева. В качестве изучаемых факторов выступали режимы орошения почвы $(60-80,70-90,80-100 \%$ наименьшей влагоемкости) и сорта («Утро» и «Машенька»). Результаты опыта показывают, что саженцы сливы, выращиваемые в условиях недостаточного и неравномерного увлажнения, характеризуются наименьшими биометрическими показателями. Наиболее сильно дефицит почвенной влаги проявляется в период интенсивного роста (май - начало июня). Недостаточное и неравномерное увлажнение
\end{abstract}


с промежутками пониженного увлажнения приводит к появлению у растений нескольких волн роста. У саженцев, которые выращиваются при капельном орошении, второй и третьей волн роста не наблюдается. В вариантах с орошением корневая система саженцев преимущественно расположена в верхнем пахотном слое почвы, который лучше всего обеспечен питательными элементами, имеет наименьшую плотность и благоприятный воздушный режим. Расположение корневой системы вдоль капельной линии и на глубине до 30 см облегчает выкопку саженцев в питомниках и приводит к их меньшему повреждению при пересадке.

Ключевые слова: капельное орошение, режим орошения, саженцы, слива

\section{БИБЛИОГРАФИЧЕСКИЙ СПИСОК}

[1] Кравиов C.A. Роль государства в развитии садоводства России // Садоводство и виноградарство. 2010. № 5. С. 14-19.

[2] Трунов Ю.В., Медведев С.М. Состояние и перспективы развития садоводства в Центральном Федеральном округе // Садоводство и виноградарство. 2009. № 5. С. 16-17.

[3] Чекмарев П.А. Состояние и перспективы развития овощеводства и садоводства в Российской Федерации // Садоводство и виноградарство. 2010. № 3. С. 5-14.

[4] Трунов Ю.В., Соловьев А.В. Состояние и перспективы развития садоводства в России. Технологические особенности современного садоводства // Вестник МичГАУ. 2012. № 3. C. $42-49$.

[5] Дадалко В.A. Продовольственная безопасность как составляющая национальной и экономической безопасности государства // Вестник УГАТУ. 2013. Т. 17. № 7. С. 17-25.

[6] Куликов И.М., Минаков И.А. Развитие садоводства в России: тенденции, проблемы, перспективы // Аграрная наука Евро-Северо-Востока. 2017. № 1. С. 9-15.

[7] Куликов И.М., Минаков И.А. Состояние и эффективность интенсификации садоводства // АПК: Экономика, управление. 2017. № 4. С. 4-15.

[8] Дубенок Н.Н., Бородычев В.В., Лытов М.Н., Белик О.А. Особенности водного режима почвы при капельном орошении сельскохозяйственных культур // Достижения науки и техники АПК. 2009. № 4. С. 22-25.

[9] Дубенок Н.Н., Бородычев В.В., Шенщева Е.В., Стрижакова Е.А., Шумакова К.Б. Выращивание баклажан при капельном орошении с использованием тоннельных укрытий для получения ранней продукции // Достижения науки и техники АПК. 2012. № 9. С. $38-42$.

[10] Дубенок Н.Н., Бородычев В.В., Богданенко М.П., Выборнов В.В., Шумакова К.Б. Технология возделывания раннего репчатого лука при капельном орошении. М.: Проспект, 2016. $176 \mathrm{c.}$

[11] Бунцевич Л.Л., Щеглов С.Н., Костюк М.А., Беседина Е.Н. Изучение эффективности выращивания скороплодных высокоурожайных саженцев яблони на подвоях категории «супер-стандарт» // Плодоводство и виноградарство Юга России. 2014. Т. 26. № 22. C. $12-20$.

[12] Майдебура В.И., Васюта В.М., Мережко И.М., Бурковский В.В. Выращивание плодовых и ягодных саженцев. Киев: Урожай. 1984. 232 с.

[13] Мережко И.М. Качество посадочного материала и продуктивность плодовых насаждений. Киев: Урожай, 1991. 152 с.

[14] Pereira A.R., Green S., Nova N.A.V. Penman-Monteith reference evapotranspiration adapted to estimate irrigated tree transpiration // Agricultural water management. 2006. Vol. 83. № 1-2. P. $153-161$. 